Sjollema, S., Hordyk, S-R., Walsh, C., Hanley, J., Ives, N. (November 2012). Found Poetry, Finding Home: A qualitative study of homeless immigrant women. Journal of Poetry Therapy. Vol. 25, No. 4, pp. 205_217

\title{
Found Poetry - Finding Home: A Qualitative Study of Homeless Immigrant Women
}

\author{
Sandra D. Sjollema ${ }^{1}$, Shawn Renee Hordyk², Christine A. Walsh ${ }^{3}$, \\ Jill Hanley ${ }^{4}$, Nicole Ives ${ }^{5}$
}

\author{
1 Sandra D. Sjollema \\ Master's student \\ School of Social Work, McGill University \\ 3506 University Street, Suite 300 \\ Montreal, Quebec, Canada H3A 2A7 \\ E-mail: sandra.dennisonsjollema@mail.mcgill.ca \\ *Corresponding author \\ 2 Shawn Renee Hordyk \\ $\mathrm{PhD}$ student \\ School of Social Work, McGill University \\ 3506 University Street, Suite 300 \\ Montreal, Quebec, Canada H3A 2A7 \\ E-mail: shawn-renee.hordyk@mail.mcgill.ca \\ 3 Christine A. Walsh, \\ Associate Professor \\ Faculty of Social Work, University of Calgary, \\ 2500 University Drive NW, \\ Calgary, Alberta, Canada T2N 1N4 \\ TEL: (403) 220-2274 \\ FAX: (403) 282-7269 \\ E-mail: cwalsh@ucalgary.ca \\ 4 Jill Hanley \\ Assistant Professor \\ Faculty of Social Work, McGill University \\ 3506 University Street, Suite 300 \\ Montreal, Quebec, Canada H3A 2A7 \\ Tel: (514) 398-4046 \\ Fax: (514) 398-4760 \\ E-mail: jill.hanley@mcgill.ca
}


Sjollema, S., Hordyk, S-R., Walsh, C., Hanley, J., Ives, N. (November 2012). Found Poetry, Finding Home: A qualitative study of homeless immigrant women. Journal of Poetry Therapy. Vol. 25, No. 4, pp. 205_217

5 Nicole Ives

Assistant Professor

Faculty of Social Work, McGill University

3506 University Street, Suite 300

Montreal, Quebec, Canada H3A 2A7

Tel: (514) 398-7065

Fax: (514) 398-4760

E-mail : nicole.ives@mcgill.ca 
Sjollema, S., Hordyk, S-R., Walsh, C., Hanley, J., Ives, N. (November 2012). Found Poetry, Finding Home: A qualitative study of homeless immigrant women. Journal of Poetry Therapy. Vol. 25, No. 4, pp. 205_217

This article considers the use of found poetry as a tool in qualitative research to examine the experience of precarious housing and homelessness among immigrant women in Montreal. Immigrant and refugee women exhibit greater risk for homelessness than women in general or male newcomers due to higher rates of poverty. Yet little is known about migrant women's experiences of homelessness and less is available from their own perspective, specifically. The article provides a context for understanding female, newcomer homelessness and summarizes the history of the found poem in a variety of disciplines with an emphasis on "social work and the arts" context. This article also details the study methodology and illustrates the process of the found poem technique with two found poems used as data representation. The found poems we present in this article reveal two of the study's key findings related to causes of homelessness: unexpected crises (tipping points) and exploitation.

Keywords: Immigrant women; found poetry; qualitative research; homelessness; social work; poetic inquiry; poetry therapy; art-based processes

Word count: 4,429 
Sjollema, S., Hordyk, S-R., Walsh, C., Hanley, J., Ives, N. (November 2012). Found Poetry, Finding Home: A qualitative study of homeless immigrant women. Journal of Poetry Therapy. Vol. 25, No. 4, pp. 205_217

\section{Found Poetry - Finding Home: A Qualitative Study of Homeless Immigrant Women}

\section{Introduction}

This article aims to contribute to the growing body of research on poetic inquiry by examining how found poetry was used to understand and portray the lived experiences of immigrant women subjected to varying degrees of homelessness. Morrissey (n.d.) defines found poetry, as "poetry which has been created using another primary source (a piece of prose, a person speaking, a list, even, in some cases, another poem by someone else). The poet shapes this original material into a poem, using the words and phrases found within the document" (para. 1). Found poetry, in a research context, is also alternately referred to as "poetic transcription" (Glesne, 1997; Richardson, 2002), "research poetry" (Langer \& Furman, 2004a), “data poetry" (Sullivan, Butler-Kisber, Commeryas, \& Stewart, 2002), or “poetic inquiry” (Butler-Kisber, 2004). Found poetry is a tool used in qualitative research where, generally speaking, words are extracted from narrative transcripts based on interviews with research subjects.

In the early 1990s, the social sciences, including social work (Furman, Lietz, \& Langer, 2006), began incorporating found poetry into their research methodology and have used it as a means of inquiry to inform practitioners, policy makers and the public about the lived experiences of a variety of vulnerable populations, including people living with HIV (Poindexter, 1998), cancer patients (Kendall \& Murray, 2005), people receiving public assistance (Connelly, 2010) and people living with mental illness (Clarke, Febbraro, Hatzipentalis, \& Nelson, 2005).

The rationale for including arts-based inquiry in qualitative research - such as the present study is that using different forms of data analysis and representation can alter the way we understand phenomena (Eisner, 1991). As such, when conducting research with vulnerable populations and relating their problems, researchers are exploring "the kinds of topics that lead into the affective experiential domain" (Prendergast, 2009, p. xxii). Traditional forms of qualitative research, such as the linear prose transcript, are considered to be less potent techniques in terms of fully capturing and evoking emotive experiences (Butler-Kisber, 2005; Shapiro, 2004; Sparkes, Nilges, Swan, \& Downing, 2003). A second consideration when using poetic transcription is that it amplifies the way voice and authorship are expressed (Furman, Langer, Davis, Gallardo, \& 
Sjollema, S., Hordyk, S-R., Walsh, C., Hanley, J., Ives, N. (November 2012). Found Poetry, Finding Home: A qualitative study of homeless immigrant women. Journal of Poetry Therapy. Vol. 25, No. 4, pp. 205_217

Kulkarni, 2007) in that it retains the signature of the research participant (Butler-Kisber, 2005). It therefore defies more traditional research methods in which researchers are seen as the authority (Glesne, 1997). Social work practice, for its part, is concerned with the empowerment of its clients (Lee, 2001) and poetry therapy, in particular, is regarded as a tool for agency for disadvantaged or oppressed populations in the social work context (Furman, Downey, Jackson, \& Bender, 2002; Kissman, 1989).

This article will be divided into several sections that will clarify the use of this technique in the context of exploratory qualitative research. First, the history and use of the found poem in various contexts will be discussed. Second, a general description of the study will be given. The methodology of the found poetry utilized in this study will then be explained as well as its meaning to the researchers involved in using the technique. Finally, two of the found poems resulting from this research will be presented, to be followed by a discussion about the implications of this work.

\section{Poetry and the found poem in literature}

Poetry has the capacity to attract humankind because of its ability to synthesize experience in a way that imparts musicality, rhythm, and poignancy (Butler-Kisber, 2010). As poet Jane Hirshfield (1997) states: "poetry's work is the clarification and magnification of being...each time we enter its word-woven and musical invocation, we give ourselves over to a different mode of knowing" (p. vii). Found poetry has an established history in American literature. Since the first half of the $20^{\text {th }}$ century, it has been used as a literary tool by American poets, especially by those interested in social justice issues (Prendergast, 2009). For example, Muriel Rukeyser (1938) used this technique in her book U.S. 1, creating poems distilled from her interviews with miners in West Virginia about their work-related health problems. Other poets to have used this technique include Ezra Pound, T.S. Eliot and Maya Angelou (Prendergast, 2006).

\section{Social work and the arts}

In the late $19^{\text {th }}$ century, the arts became an important tool in social work practice as witnessed in the Settlement Movement, a reformist social movement in the U.S. and Britain, which identified popular participation in the arts as an important goal (Getzel, 1983). Creative expression has long 
Sjollema, S., Hordyk, S-R., Walsh, C., Hanley, J., Ives, N. (November 2012). Found Poetry, Finding Home: A qualitative study of homeless immigrant women. Journal of Poetry Therapy. Vol. 25, No. 4, pp. 205_217

been associated with social group work (Cohen \& Johnson, 1997). More recently, poetry therapy has become an important tool in social work practice with a wide variety of vulnerable populations as witnessed by looking at any reference page of an article on poetry therapy, for example in Lerner's (1997) article. One example of an application of found poetry in social work group therapy is a version called the collaborative poem, where group members take preexisting texts (usually composed by the individual participants themselves) and combine a variety of words and phrases to contribute to a group poem (Golden, 2000).

\section{The poem and found poem in research}

Qualitative, as opposed to quantitative research has always had as a goal to "penetrate into the depths of human experience: to search into the heart of matters" (Furman, 2004, p. 162). As such, qualitative researchers in such disciplines as anthropology (Madison, 2008; McConochie, 1986), education (Finley, 2000) and social work (Shafer, Maxwell, Strauss, \& Knopp, 2007) began, in the late 1980s and early 1990s, to experiment with poetic inquiry, a specific form of artsinformed processes (Butler-Kisber, 2010) that had gained the attention of academic researchers. The goals in using these new arts-based techniques included making research more embodied and evoking "intellectual, aesthetic and affective responses" (Butler-Kisber, 2010, p. 4) in the consumers of the research.

Poetic inquiry can be broadly defined as the process of writing research poems that helps the researcher develop new insights (Prendergast, 2004). Two forms of poetic inquiry have been predominantly utilized in qualitative research: the research or found poem and the generated or interpretive poem (Faulkner, 2007). The latter involves the researcher writing original poems, either as a means of reflecting on collected data (Prendergast, 2004) or in response to a - usually personal - situation, for example, a father's diagnoses of lung cancer (Furman, 2004). Both found and generative poems can be used, in turn, as a means of data analysis and data representation (Furman et al., 2007) or simply as an analytic tool that leads to insight (ButlerKisber, 2005). 
Sjollema, S., Hordyk, S-R., Walsh, C., Hanley, J., Ives, N. (November 2012). Found Poetry, Finding Home: A qualitative study of homeless immigrant women. Journal of Poetry Therapy. Vol. 25, No. 4, pp. 205_217

Butler-Kisber (2005) describes found poetry in a research context as the process of taking words, phrases, or whole passages found in data - usually narrative-style interview data - and reframing them as poetry by changing the spacing, line breaks, and by adding and deleting certain words. Langer and Furman (2004b) believe that the found poem may be useful as an alternative means of presenting the participant's voice as the primary transmitter of data. Researchers have ascribed strengths or advantages in using the found poetry technique, including:

$>$ it honors the styles, words, rhythms, and syntax of everyday speech (Richardson, 2002) because the narratives people tell fit naturally into poetic structure (Poindexter, 2002);

$>$ it is an extremely effective form of communicating lived experience (Connelly, 2010; Richardson, 1993);

$>$ it is a form of description that can represent a movement towards truly understanding the respondent instead of just re-stating the conversation (Geertz, 1973); and

$>$ it is effective for advocacy purposes as its compressed form lends itself to various media (Langer \& Furman, 2004b).

All of these attributes encouraged us, as researchers, to explore this method as we sought to analyze and represent immigrant women's experiences with housing and homelessness.

\section{Uncovering invisibilities: Immigrant, female and homeless}

This study, carried out by a team of social work researchers at McGill University and the University of Calgary, sought to address the gaps created by the paucity of research directed at understanding, uncovering and exploring housing insecurity and homelessness of women newcomers. The goals of the study included informing policy makers, practitioners and the general public as to the lived experiences of migrant women across the homeless spectrum.

The homeless experiences of migrant women have been the subject of few investigations, typically subsumed within categories of Canadian- born women's homelessness or general themes of newcomers' housing insecurity, both of which are different than the realities of homeless newcomer women. For example immigrant/refugee women exhibit greater risk for 
Sjollema, S., Hordyk, S-R., Walsh, C., Hanley, J., Ives, N. (November 2012). Found Poetry, Finding Home: A qualitative study of homeless immigrant women. Journal of Poetry Therapy. Vol. 25, No. 4, pp. 205_217

homelessness than women in general or male newcomers due to higher rates of poverty (Canadian Association of Social Workers, 2004; Saraswatisi, 2000). As the direct experiences of homeless persons have been absent in informing solutions (Acosto \& Toro, 2001), the goal of this project has been to include homeless immigrant/refugee women in outlining specific needs and policy solutions. As they are experts on the issues, inclusion helps to ensure the policies and interventions are responsive to their needs (Lombe \& Sherraden, 2008).

Definitions of homelessness include both lacking shelter and living with precarious housing (Begin, Casavant, Miller Chenier, \& Dupuis, 1999). In addition to experiencing barriers to housing shared by their Canadian born counterparts, homeless women migrants are marginalized by their invisibility (Fiedler, Schuurman, \& Hyndman, 2006). Few use shelters or social services (Preston et al., 2009), often not knowing which services exist. Migrant women may also face barriers to emergency or temporary shelters due to language barriers and lack of culturally appropriate services (Shirwadkar, 2004; Tutty, Thurston, Christensen, \& Eisener, 2003).

\section{Finding home through found poetry: The research project}

With the goal of documenting immigrant women's experiences of housing insecurity and homelessness, this project sought methods that would allow women with various immigration statuses to express themselves and share their understandings of their situations. Semi-structured interviews were implemented in order to invite the perspectives of migrant women experiencing precarious housing. Women were recruited either by word of mouth or advertisements posted in local shelters, immigrant settlement agencies, and women's centers. Interview questions were divided into the following themes: life history and immigration experiences, history of housing insecurity in Canada, current housing situation, personal survival strategies and coping mechanisms, health concerns, community resources which they have found helpful, and recommendations for policy and practice.

After significant groundwork to recruit this difficult-to-reach population, 26 women took part in the study, all but one of whom had arrived in Montreal within the past 10 years. The majority of respondents were between the ages of 20 and 40 and had come from a wide variety of ethnic and 
Sjollema, S., Hordyk, S-R., Walsh, C., Hanley, J., Ives, N. (November 2012). Found Poetry, Finding Home: A qualitative study of homeless immigrant women. Journal of Poetry Therapy. Vol. 25, No. 4, pp. 205_217

national backgrounds, and most were women of color. Many of the study participants had minor children and the majority had high school and /or college degrees and significant work experience in their countries of origin. Most of the women interviewed were either unaccompanied by a spouse or unmarried at the time of the interview.

Statements from the women consistently demonstrated that the primary cause of housing insecurity for newcomer women is that of inadequate income in the face of rising housing costs. Discrimination due to presence of children, or ethnicity, a history of trauma, and language barriers were cited by many women as prohibitive factors in finding stable housing.

As the migrant women brought their stories to life, researchers began to look for a means through which this diversity of voices could be represented to the government, to organizations serving migrant women, and to the community at large. A close reading of the transcripts revealed six major causative factors in newcomer women's homelessness: discrimination, unexpected crises (tipping points), exploitation, isolation, poor living conditions, and personal histories of emotional and mental suffering. In order to communicate these themes to members of the general public and to homeless women or women experiencing housing insecurity themselves, the team created a series of vignettes to illustrate women's experiences. A textile artist was also invited to create works symbolically representing these vignettes.

\section{Using found poetry: Method and meaning}

Found poetry had not been the original intention of this research team. The initial proposal contained a plan to do an audio-visual presentation of the women telling parts of their story. This proved challenging as the transient nature of many women interviewed and the relative complexity of their lives meant that we would not have been able to relocate many of the participants, few would have had the time to participate in the video-making and their visibility in video-making would have been problematic for this marginalized and oppressed population. Found poetry was chosen instead to accomplish a similar goal: to represent the women's experiences in their own voices. Contrary to the case studies in which researchers imposed their 
Sjollema, S., Hordyk, S-R., Walsh, C., Hanley, J., Ives, N. (November 2012). Found Poetry, Finding Home: A qualitative study of homeless immigrant women. Journal of Poetry Therapy. Vol. 25, No. 4, pp. 205_217

own language while attempting to most accurately represent the content of the interviews, found poetry featured the women's voices directly in ways that protected their confidentiality.

The poems were written by four team members who used slightly different approaches in creating the found poetry. Some used the audio recordings and transcripts of the interviews to write the poem; others used only the transcripts and one wrote poetry based on select excerpts from the interview transcripts. Although no words were altered, researchers used "poetic license" (Butler-Kisber, 2010, p. 87) and re-arranged the words in a different order than in the original text using repetition for emphasis. Of those who constructed the poems, all had experience in writing as well as an interest in poetry though only one individual had extensive experience in writing poetry, having published in the field. None of the writers had implemented this method of data representation in prior research projects.

As the researchers read through the transcripts, they looked for words, phrases and manners of expression that repeated themselves. Butler-Kisber (2002) describes attempting to replicate the interviewee's unique rhythm, pauses, emphasis, breath-points, syntax and diction (p. 233). The writers also highlighted the words, phrases and expressions that appeared to most poignantly capture a specific aspect of a woman's monologue. These words were then placed in a way that punctuated specific themes.

The meaning of the found poetry writing experience varied from writer to writer. For those who had followed the stories of the women from the beginning of the project, the writing of the poetry 'altered' the way in which the phenomena was understood (Eisner, 1991). The meaning of the women's narrative had already become visible through the physical interview, followed by transcribing, coding and discussion - an already thorough process. Yet the act of found poetry writing invited reflection on other aspects of each woman's story: not only what she said but how she said it, not only the subdivided categories of themes but the overall theme that she may have wished to convey. In one particular instance, the attunement of the researcher-writer to the above-mentioned factors in poetic construction was especially compelling. One woman had experienced significant emotional pain and suffering in her country of origin, having lived in a 
Sjollema, S., Hordyk, S-R., Walsh, C., Hanley, J., Ives, N. (November 2012). Found Poetry, Finding Home: A qualitative study of homeless immigrant women. Journal of Poetry Therapy. Vol. 25, No. 4, pp. 205_217

refugee camp. Once again finding herself homeless, her emotional condition deteriorated. Her interview narrative was disjointed and difficult to follow. Putting her words into poetry meant conveying her rapidly changing thought patterns while looking for the underlying thread linking her narrative to the place at the center of her poem. In this case, a dual interconnected theme became evident, that of transience and a search for stability. The found poem remained true to this woman's communication style while allowing the reader access to the reality and the strength of her story.

To be sure, found poetry has an interpretive component and to some degree represents the subjective experience of the writer. However, this does not preclude the fact that writing found poetry or reading the rendition of another provided added insights in data analysis for this particular project. For example, one of the women described her building sense of helplessness and frustration as landlords asked her which country she was from and, on hearing her response, would refuse her an apartment. She resolved this problem one day by emphatically asserting to the landlord that she belonged, telling him that she was a citizen, and was granted her apartment. This phrase was taken from the middle of her interview and used to conclude her poem. These three words reflected her strength, while also communicating the challenge expressed by many of the women who fought language, social, ethnic and economic barriers to be recognized as people who belonged and deserved respect and dignity.

For those who entered the writing project after the research had been conducted and the interviews transcribed and discussed, the meaning was also significant. One of the writers was also engaged in research with immigrant women and found the interviews enlightening, contributing to her understanding of the unique challenges faced by migrant women as well as confirming the many strengths that she had also experienced with this population. For the team member with extensive poetic experience, the found poetry exercise represented an artistic challenge as it was the first time this individual had crafted poems from narrative text. For this member, the exercise also permitted a coming together or two distinct and compelling interests in her life: poetry and social justice issues. 
Sjollema, S., Hordyk, S-R., Walsh, C., Hanley, J., Ives, N. (November 2012). Found Poetry, Finding Home: A qualitative study of homeless immigrant women. Journal of Poetry Therapy. Vol. 25, No. 4, pp. 205_217

The next sections share two of the found poems and discuss the creation processes. The first found poem is based on the narrative of a young woman from the Philippines who came as a domestic worker through a temporary foreign worker program. The second poem is based on the narrative of woman from Central Africa whose homeless trajectory began as an asylum seeker. In both cases pseudonyms are used and some details are altered to protect the women's identities.

\section{Migrant women seeking home: Understanding through poetry}

Anna made the difficult decision to leave her husband and children behind in the Philippines when her children were young. She came to Montreal through the Live-in Caregiver Program (LCP), where women work as caregivers to children, seniors or people with disabilities while living in the home of the employer for a period of up to four years (Citizenship and Immigration Canada, n.d.) After this time, and under certain conditions, they can apply for Permanent Residence status and remain in the country as well as sponsor relatives to join them. Between airfare fees paid to the agency that found her an employer and other costs, Anna paid nearly four thousand dollars to come to North America. However, once having arrived, she was told that the employer who had requested her had changed his mind. As a newcomer, she suddenly had no place to live and no finances to return home. She found herself dependent on the agency to arrange for food and lodging. She ended up living in very overcrowded quarters provided by the agency with a number of other Filipina women. Eventually she found a second position as a caregiver, but when she became ill, was fired. She finally ended up with a third family in a rural location where conditions were described as much better. During this time, she continued to send whatever money she had available in the form of remittances to relatives in the Philippines.

The notion of space and of not having a room of one's own, or enough room, was a recurrent theme in Anna's story. In addition, the precarious nature of being reliant on an employer for lodging, of finding new accommodations quickly and having to settle for what one can find was 
Sjollema, S., Hordyk, S-R., Walsh, C., Hanley, J., Ives, N. (November 2012). Found Poetry, Finding Home: A qualitative study of homeless immigrant women. Journal of Poetry Therapy. Vol. 25, No. 4, pp. 205_217

another leitmotif in Anna's story. Most importantly, the sacrifice of being away and longing for her children was the overarching sentiment she expressed.

Six in one room

A three and $a$ half

Sleep in the kitchen

in the living room

Some of our income to the Philippines

Family, children in the Philippines

Bring them from the Philippines

Live-in, live-out

Caregiver program

Not enough room of your own

Fired, hired, fired

Illegal work

A new job in the Eastern Townships

A member of the family

A big sacrifice

And longing

Nayika is over 50 years of age. She migrated almost 10 years ago from Burundi and, through her church work, ended up living with people from her country of origin. This family promised protection, a home and a job looking after the family's children. Unfortunately, Nayika was never paid after almost a year of labor and her employers/friends became abusive. As she did not have permanent residency status and was an asylum claimant, she had no recourse to defend her rights. Another person from her country of origin offered to step in and help her out by offering her a room in his three-bedroom home. This individual also abused her trust when he insisted 
Sjollema, S., Hordyk, S-R., Walsh, C., Hanley, J., Ives, N. (November 2012). Found Poetry, Finding Home: A qualitative study of homeless immigrant women. Journal of Poetry Therapy. Vol. 25, No. 4, pp. 205_217

that she share the bedroom with him. This proposition was against her religious beliefs and unacceptable to her. Nayika ended up being evicted and, with nowhere to turn to, living, for a brief period of time, on the streets. .. After much time and effort, Nayika managed to get both somewhat reasonable lodgings of her own and eventually, citizenship.

Nayika's story represents another dilemma faced by many immigrant women. Women who migrate alone often do so because they have relatives or friends who have previously immigrated and who they intend to join. Women in this situation identified that those from their own country are best suited to help them through the immigration and integration processes because of a shared language, dietary habits and cultural background. These migrant women may end up living with these relatives or friends but, in many cases, the relationships are only acquaintances from their home country or people they met upon arrival. In either case, the women are in a state of utter dependency on these people. Unfortunately, these situations often do not turn out for the best: people are often living in very cramped conditions, there can be personality conflicts, and sometimes the newcomer women, as was the case with Nayika, find themselves subjected to abuse and betrayal. They are then forced to find alternative lodging as a result.

In reviewing Nayika's story, the emotion of betrayal was the overwhelming sentiment expressed. The fact that she had trusted acquaintances from her country of origin to help her and that these people at the outset seemed friendly and welcoming led to Nayika's feeling of deception. In the end, it is obvious that she has been taken advantage of. The sentiment of betrayal was characterized by the repetition of the phrase "I trusted them", which is also the title of the poem.

\section{I trusted them}

I felt protected

Living with people

They had been in this country for a long time

They knew all the rules

They are people from my own place

I was alone, I didn't have family

\section{I trusted them}


Sjollema, S., Hordyk, S-R., Walsh, C., Hanley, J., Ives, N. (November 2012). Found Poetry, Finding Home: A qualitative study of homeless immigrant women. Journal of Poetry Therapy. Vol. 25, No. 4, pp. 205_217

They welcomed me

Ifelt I met

Like friends, like family

Ifelt safe with them

I trusted them

I worked hard

For a whole year, not getting my pay

I did not know what to do

I still did not have my papers

\section{I trusted them}

\section{Discussion}

The two poems detailed in this article represent the reality of many migrant newcomer women. Found poetry representation allows readers to feel the sense of constrained space, lodging insecurity and dependency that is too often the experience of this population. The feelings expressed in the two poems - longing in the first poem and betrayal in the second - allow for a more visceral understanding of the situation of the two women interviewed.

As previously mentioned, found poetry is considered to be an effective technique to express the everyday reality of people, in particular that of vulnerable populations who often live in constant states of heightened emotion such as fear, helplessness, anger or dread. In research, there is often a paucity of data that reflects the realities of these populations, as certainly is the case in newcomer women struggling to find adequate housing. It could be said, then, that using the found poetry technique in this study helps fill the gaps in the research and does so in a highly evocative manner. 
Sjollema, S., Hordyk, S-R., Walsh, C., Hanley, J., Ives, N. (November 2012). Found Poetry, Finding Home: A qualitative study of homeless immigrant women. Journal of Poetry Therapy. Vol. 25, No. 4, pp. 205_217

As one of the goals of this study is to inform the public of the lived experience of newcomer women in terms of housing insecurity and homelessness, found poetry is an effective technique in that it too has as a goal the accessibility of information to the consumers of research.

The second group targeted by this study are practitioners who offer services to immigrant women, whether it be in homeless shelters, women's centers or other community-based organizations. For practitioners, the found poetry technique offers an alternative means of understanding and communicating the day-to-day realities of their clientele other than the usual annual or community-based reports that often rely on statistics or interview-style narratives.

The final consumers of this research are the policy makers at the government level. According to Connelly (2010), found poetry allows the connection from the personal to the public sphere to occur because, as policy is necessarily linked with everyday events, re-presenting the day-to-day lives of those directly affected by these policies through poetry allows for policy evaluation. Connelly, who used the data poem technique in her research with low-income Australians, states that "through these poems it becomes possible to pinpoint those policies that have a negative impact.... and how they might be more appropriately designed to assist rather than disadvantage"(p. 38).

Ultimately, social work and other social science researchers may decide to incorporate the found poetry technique along with more conventional forms of research as an alternate and potent form of presenting data. There is certainly much room for exploration and development in this area, especially when it comes to relating the lived experiences of immigrant populations.

\section{Conclusion}

This article has sought to locate the found or research poem in its historical and interdisciplinary contexts. Poetic techniques, particularly found poetry - the technique that extracts words and phrases from narrative text to create poetic form - have a history in literature, the social sciences and within a social work framework. That social work researchers would now incorporate this specific technique when conducting qualitative studies lies well within the values of the 
Sjollema, S., Hordyk, S-R., Walsh, C., Hanley, J., Ives, N. (November 2012). Found Poetry, Finding Home: A qualitative study of homeless immigrant women. Journal of Poetry Therapy. Vol. 25, No. 4, pp. 205_217

tradition: to empower vulnerable populations and value their lived experiences. By presenting two found poems about housing insecurity among newcomer migrant women, it is hoped that the potency of such a technique has become evident as well as its capacity to help consumers understand experience in a different way. By revealing certain results of their study through two found poems, this research team hopes to contribute to the growing body of research on poetic inquiry, especially in a social work context.

\section{Acknowledgements}

This study was funded by Human Resources Skill Development Canada (HRSDC) Homeless Partnering Secretariat 
Sjollema, S., Hordyk, S-R., Walsh, C., Hanley, J., Ives, N. (November 2012). Found Poetry, Finding Home: A qualitative study of homeless immigrant women. Journal of Poetry Therapy. Vol. 25, No. 4, pp. 205_217

\section{References}

Acosto, O., \& Toro, P. (2001). Let's ask the homeless people themselves: A needs assessment on a probability sample of adults. American Journal of Community Psychology, 29(3), 343366. doi: 10.1023/A:1005105421548

Begin, P., Casavant, L., Miller Chenier, N., \& Dupuis, J. (1999). Homelessness. Parliamentary Research Branch. Ottawa: Library of Parliament.

Butler-Kisber, L. (2002). Artful portrayals in qualitative research: The road to found poetry and beyond. The Alberta Journal of Educational Research, 48, 229-239.

Butler-Kisber, L. (2004). Poetic inquiry. Journal of Critical Inquiry into Curriculum and Instruction, 5(1), 1-4.

Butler-Kisber, L. (2005). Inquiry through poetry: The genesis of self-study. In C. Mitchell, S. Weber, \& K. O'Reilly-Scanlon (Eds.), Just who do we think we are? Methodologies for autobiography and self-study in teaching (pp. 95-110). New York: Routledge Falmer.

Butler-Kisber, L. (2010). Qualitative Inquiry: Thematic, Narrative and Arts-Informed Perspectives. London: Sage Publications.

Canadian Association of Social Workers. (2004). Women's income and poverty in Canadarevisted. Retrieved http://casw-acts.ca/advocacy/womenpoverty_e.pdf

Citizenship and Immigration Canada. (n.d.). Backgrounder — Four-year limit for foreign nationals working in Canada. Retrieved http://www.cic.gc.ca/english/department/media/backgrounders/2011/2011-03-24.asp

Clarke, J., Febbraro, A., Hatzipentalis, M., \& Nelson, G. (2005). Poetry and prose: Telling the stories of formerly homeless mentally ill people. Qualitative Inquiry, 11(6), 913-932. doi: $10.1177 / 1077800405278772$ 
Sjollema, S., Hordyk, S-R., Walsh, C., Hanley, J., Ives, N. (November 2012). Found Poetry, Finding Home: A qualitative study of homeless immigrant women. Journal of Poetry Therapy. Vol. 25, No. 4, pp. 205_217

Cohen, M.B. \& Johnson, J.M. (1997). Self-directed community group for homeless people: Poetry in motion. In J.K. Parry (Ed.), From Prevention to Wellness through Group Work(pp. 131-142). New York, London: The Hawarth Press.

Connelly, K. (2010). What body parts do I need to sell? Poetic re-presentations of experiences of poverty and fear from low-income Australians receiving welfare benefits. Creative Approaches to Research, 3(1), 16-41. doi: 10.3316/CAR0301016

Eisner, E.W. (1991). The enlightened eye. New York: Macmillan.

Faulkner, S. L. (2007). Concern with craft: Using Arts Poetica as criteria for reading research poetry. Qualitative Inquiry, 13(2), 218-234. doi: 10.1177/1077800406295636

Fiedler, R., Schuurman, N., \& Hyndman, J. (2006). Hidden homelessness: An indicator-based approach for examining the geographies of recent immigrants at-risk of homelessness in Greater Vancouver. Cities, 23(3), 205-216. doi: doi:10.1016/j.cities.2006.03.004

Finlay, S. (2000). 'Dream child': The role of poetic dialogue in homeless research. Qualitative Inquiry, 6(3), 432-434. doi: 10.1177/107780040000600309

Furman, R. (2004). Using poetry and narrative as qualitative data: Exploring a father's cancer through poetry. Families, Systems \& Health, 22(2), 162-170. doi: 10.1037/10917527.22 .2 .162

Furman, R., Downey, E.P., Jackson, R.L., \& Bender, K. (2002). Poetry therapy as a tool for strengths-based practice. Advances in Social Work, 3(2), 146-157. Retrieved http://journals.iupui.edu/index.php/advancesinsocialwork/article/view/36/30

Furman, R., Langer, C.L., Davis, C.S., Gallardo, H.P., \& Kulkarni, S. (2007). Expressive, research and reflective poetry as qualitative inquiry: a study of adolescent identity. Qualitative Research, 7(3), 301-315. doi: 10.1177/1468794107078511 
Sjollema, S., Hordyk, S-R., Walsh, C., Hanley, J., Ives, N. (November 2012). Found Poetry, Finding Home: A qualitative study of homeless immigrant women. Journal of Poetry Therapy. Vol. 25, No. 4, pp. 205_217

Furman, R., Lietz, C. \& Langer, C.L. (2006). The research poem in international social work. International Journal of Qualitative Methods, 5(3), 24-34. Retrieved http://ejournals.library.ualberta.ca/index.php/IJQM/article/view/4368/3498

Geertz, C. (1973). The Interpretation of Cultures. New York: Basic Books.

Getzel, G.S. (1983). Poetry writing groups and the elderly: A reconsideration of art and social group work. In R. Middleton (Ed.), Actions and Action in Group Work (pp. 65-76). New York: Routledge.

Glesne, C. (1997). That rare feeling: Re-presenting research through poetic transcription. Qualitative Inquiry 3(2), 202-221. doi: 10.1177/107780049700300204

Golden, K.M. (2000). The use of collaborative writing to enhance cohesion in poetry therapy groups. Journal of Poetry Therapy, 13(3),125-138. doi: 10.1023/A:1021473712505

Hirschfield, J. (1997). Nine gates: Entering the mind of poetry. New York: Harper Perennial.

Kendall, M. \& Murray, S.A. (2005). Tales of the unexpected: Patients' poetic accounts of the journey to a diagnosis of lung cancer. A prospective serial qualitative interview study. Qualitative Inquiry, 11(5), 733-751. doi: 10.1177/1077800405276819

Kissman, K. (1989). Poetry and feminist social work. Journal of Poetry Therapy, 2(4), 221-230.

Langer, C. \& Furman, R. (2004a). The Tanka as a qualitative research tool: A study of a Native American woman. Journal of Poetry Therapy, 17(3), 165-171. Retrieved http://dx.doi.org/10.1080/08893670412331311334

Langer, C. \& Furman, R. (2004b). Exploring identity and assimilation: Research and interpretive poems. Forum Qualitative Sozialforschung/Forum: Qualitative Social Research, 5(2), article 5. Retrieved http://nbn-resolving.de/urn:nbn:de:0114-fqs040254. 
Sjollema, S., Hordyk, S-R., Walsh, C., Hanley, J., Ives, N. (November 2012). Found Poetry, Finding Home: A qualitative study of homeless immigrant women. Journal of Poetry Therapy. Vol. 25, No. 4, pp. 205_217

Lee, J.A.B. (2001). The empowerment approach to social work practice: Building the beloved community. New York, Chichester, West Sussex: Columbia University Press.

Lerner, A. (1997). A look at poetry therapy. The Arts in Psychotherapy, 24(1), 81-89. Retrieved http://www.sciencedirect.com/science?_ob=MiamiImageURL\&_cid=271820\&_user4585 07\&_pii=S019745569600055X\&_check=y\&_origin=gateway\&_coverDate=31-Dec$\underline{1997 \& v i e w=c \& w c h p=d G L b V 1 S-z S k z V \& m d 5=0421 f 3 c 25839 d 120897 d 7 c 5450 b 9310 / 1-}$ s2.0-S019745569600055X-main.pdf

Lombe, M. \& Sherraden, M. (2008). Inclusion in the policy process: An agenda for participation of the marginalized. Journal of Policy Practice, 7(2), 199-213. Retrieved http://dx.doi.org/10.1080/15588740801938043

Madison, D.S. (2008). Narrative poetics and performative interventions. In N.K. Denzin \& M.D. Giardina (Eds.), Qualitative inquiry and the politics of evidence, (pp. 221-249). Walnut Creek, CA: Left Coast Press.

McConochrie, R.P. (1986). Three poems from the Alps. Anthropology and Humanism Quarterly, 11(1), 15-16. doi: 10.1525/ahu.1986.11.1.15

Morrissey, K. (n.d.) Exploring poetic techniques: Found poetry. Retrieved http://www.purplepoets.com/foundpoem.html

Poindexter, C.C. (1998). Poetry as data analysis: Honoring the words of research participants. Reflections, Summer: 22-27. Retrieved http://vnweb.hwwilsonweb.com/hww/resultscommon.jhtml;hwwilsonid=JMAZ00EUBP YGHQA3DIOSFGGADUNGIIV0

Poindexter, C.C. (2002). Meaning from methods: Re-presenting narratives of an HIV-affected caregiver. Qualitative Social Work, 1(1), 59-78. doi: 10.1177/147332500200100105 
Sjollema, S., Hordyk, S-R., Walsh, C., Hanley, J., Ives, N. (November 2012). Found Poetry, Finding Home: A qualitative study of homeless immigrant women. Journal of Poetry Therapy. Vol. 25, No. 4, pp. 205_217

Prendergast, M. (2004). Shaped like a question mark: Found poetry from Herbert Blau's The Audience. Research in Drama Education, 9(1), 73-92. Retrieved http://www.tandfonline.com/doi/pdf/10.1080/1356978042000185920

Prendergast, M. (2006). Found poetry as literature review. Qualitative Inquiry, 12(2), 369-388. doi: $10.1177 / 1077800405284601$

Prendergast, M. (2009). The phenomenom of poetry in research. "Poem is what?" Poetic Inquiry in Qualitative Social Science. In M. Prendergast, C. Leggo, P. Sameshima (Eds.), Poetic Inquiry: Vibrant Voices in the Social Sciences (pp. xix-xxi). Rotterdam: Sense Publishers.

Preston, P., Murdie, R., Wedlock, J., Agrawal, S., Anucha, U., D’Addario, S., Kwak. M. J., Logan, J., \& Murnaghan, A. M. (2009). Immigrants and homelessness — at risk in Canada's outer suburbs. The Canadian Geographer, 53(3), 288-304. doi: 10.1111/j.15410064.2009.00264.x

Richardson, L. (1993). Poetics, dramatics, and transgressive validity: The case of the skipped line. The Sociological Quarterly, 34(4), 695-710.doi: 10.1111/j.15338525.1993.tb00113.x

Richardson, L. (2002). Poetic representation of interviews. In J.F. Gubrium \& J.A. Holstein (Eds.), Handbook of interview research: Context and method (pp. 887-891). Thousand Oaks, CA: Sage.

Rukeyser, M. (1938). US 1 .New York: Covici, Friede. 
Sjollema, S., Hordyk, S-R., Walsh, C., Hanley, J., Ives, N. (November 2012). Found Poetry, Finding Home: A qualitative study of homeless immigrant women. Journal of Poetry Therapy. Vol. 25, No. 4, pp. 205_217

Saraswatisi, J. (2000). Poverty and visible minority women in Canada. Canadian Women Studies, 20(3), 49-53. Retrieved http://pi.library.yorku.ca/ojs/index.php/cws/article/view/12664/11747

Shafer, A., Maxwell, B., Strauss, R. \& Knopp, V. (2007). I must tell you a poem: Poetry and commentary. Journal of Medical Humanities, 28(2), 173-180. doi: 10.1007/s10912-0079037-x

Shapiro, J. (2004). Can poetry be data? Potential relationships between poetry and research. Families, Systems \& Health, 22(2), 171-177. doi: 10.1037/1091-7527.22.2.171

Sparkes, A.C., Nilges, L., Swan, P., \& Downing, F. (2003). Poetic representation in sport and physical education: Insider perspectives. Sport, Education and Society, 8(2), 153-177. Retrieved http://www.tandfonline.com/doi/pdf/10.1080/13573320309256

Shirwadkar, S. (2004). Canadian domestic violence policy and Indian immigrant women.

Violence Against Women, 10(8), 860-879. doi: 10.1177/1077801204266310

Sullivan, A., Butler-Kisber, L., Commeryas, M., \& Stewart, M. (2002). Constructing data poems: How and why - A hands-on experience. Extended pre-conference session at the Annual Meeting of the American Educational Research Association. New Orleans, LA. (April).

Tutty, L. M., Thurston, W. E., Christensen, J. \& Eisener, A. (2003). Evaluation of the CDVC Domestic Violence Training and Protocol Project for Immigrant Serving Agencies. Report for the Calgary Domestic Violence Committee. Calgary, AB: RESOLVE Alberta 